\title{
Nursing Leadership, Associated Sociodemographic and Professional Factors: The Perception of Leaders and Evaluators*
}

Theme: Evidence-based practice.

Contribution to the subject: In its routine work, Nursing has the responsibility of coordinating the tasks and the work team with which health professionals interact daily; it is for this reason that this research intends to be a model for the institutions to assess leadership styles in their collaborators to reap the benefits inherent to conducting work teams, especially in the health area, understanding leadership as one of the most booming competences nowadays, positioning itself as an important cornerstone in the organizations and seeking, through leadership, improvements in processes, performance, and work efficiency, leading them to the attainment of institutional goals and strategies, in addition to being related to work satisfaction and to a direct improvement in the provision of health services in aspects such as the patient safety programs, quality, and health management indicators.

\section{ABSTRACT}

Objective: To assess the leadership styles of the assistance Nursing professionals and their associated sociodemographic and professional factors. Materials and methods: An analytical and cross-sectional study. The sample comprised 75 Nursing professionals and 170 Nursing assistants selected for convenience. The Multifactorial Leadership Questionnaire was applied to assess leadership and the organizational result variables. Results: The predominant leadership styles were as follows: transformational (mean of 3.43) and transac-

\section{DOI: 10.5294/aqui.2021.21.2.5}

To reference this article / Para citar este artículo / Para citar este artigo Valbuena-Durán LD, Ruiz M, Páez AN. Nursing Leadership, Associated Sociodemographic and Professional Factors: The Perception of Leaders and Evaluators. Aquichan. 2021;21(2):e2125. DOI: https://doi.org/10.5294/aqui.2021.21.2.5

* This article derives from the master's thesis entitled "Nursing leadership styles and associated sociodemographic factors. Perception of leaders and evaluators from a tertiary-level Health Care Institution in the city of Bucaramanga", presented to the Master's Degree Program in Health Services Management of Universidad de Santander in the city of Bucaramanga-Colombia.

$1 \bowtie$ https://orcid.org/0000-0002-0577-6559. Health College, Universidad Industrial de Santander, Colombia. Idvaldur@correo.uis.edu.co

2 https://orcid.org/0000-0002-8598-3354. Health College, Universidad Industrial de Santander, Colombia. myriam@uis.edu.co

3 https://orcid.org/0000-0003-0010-7564. Health Sciences College, Universidad de Santander, Colombia. ast.paez@mail.udes.edu.co
Received: $23 / 08 / 2020$

Sent to peers: $31 / 08 / 2020$

Approved by peers: $26 / 03 / 2021$

Accepted: 28/04/2021 
tional (3.40), which presented high correlation rates with satisfaction, efficacy and additional effort. The leadership style least perceived by the staff was corrective/avoidance (2.10). In transformational leadership, behavioral influence and inspirational motivation presented better scores in the leaders' self-perception. Age, marital status and having children evidenced statistically significant differences with the transformational and transactional leadership styles; work experience was significant with transactional leadership. Conclusions: In their work, Nursing professionals denote encouraging practices that are inherent to transformational leadership, which is related to changes in the organizational culture, leads to motivating and inspiring the subordinates to transcend the routines and increases their satisfaction and commitment to their duties, thus being an important factor in health institutions.

KEYWORDS (SOURCE: DeCS)

Leadership; nursing; hospital administration; health management; health personnel. 


\section{Liderazgo en enfermería, factores sociodemográficos y profesionales asociados: percepción de líderes y clasificadores*}

\section{RESUMEN}

Objetivo: evaluar los estilos de liderazgo de los profesionales de enfermería asistencial y sus factores sociodemográficos y profesionales asociados. Materiales y métodos: estudio de corte transversal analítico. La muestra correspondió a 75 profesionales de enfermería y 170 auxiliares de enfermería seleccionados a conveniencia. Se aplicó el instrumento Multifactorial Leadership Questionnaire para la evaluación del liderazgo y las variables de resultado organizacional. Resultados: los estilos de liderazgo predominantes fueron el transformacional (promedio 3,43) y transaccional $(3,40)$, estos presentaron alta correlación con la satisfacción, eficacia y esfuerzo extra. El liderazgo correctivo/evitador fue el menos percibido por el personal $(2,10)$. En el liderazgo transformacional, la influencia conductual y la motivación inspiracional presentaron mejores puntajes desde la autopercepción de los líderes. Se evidenciaron diferencias estadísticamente significativas con la edad, estado civil y tener hijos con el liderazgo transformacional y transaccional; la experiencia laboral fue significativa con el liderazgo transaccional. Conclusiones: los profesionales de enfermería denotan en su desempeño el estimular prácticas propias del liderazgo transformacional, lo cual está relacionado con cambios en la cultura organizacional, conlleva a motivar e inspirar a los seguidores para trascender lo rutinario, incrementa su satisfacción y compromiso en sus labores siendo un factor importante en las instituciones de salud.

\section{PALABRAS CLAVE (Fuente: DeCS)}

Liderazgo; enfermería; administración hospitalaria; gestión en salud; personal de salud.

\footnotetext{
* Este artículo es derivado de la tesis de maestría titulada "Estilos de liderazgo en enfermería y factores sociodemográficos asociados. Percepción de líderes y clasificadores de una Institución de salud de tercer nivel de atención de la ciudad de Bucaramanga", presentada al Programa de Maestría en Gestión de Servicios de Salud de la Universidad de Santander de la ciudad de Bucaramanga-Colombia.
} 


\section{Liderança em enfermagem, fatores sociodemográficos e profissionais associados: percepção de líderes e enfermeiros classíficadores*}

\section{RESUMO}

Objetivo: avaliar os estilos de liderança dos profissionais de enfermagem assistencial e seus fatores sociodemográficos e profissionais associados. Materiais e métodos: estudo de corte transversal analítico. A amostra correspondeu a 75 profissionais de enfermagem e 170 auxiliares de enfermagem selecionados por conveniência. Foi aplicado o instrumento Multifactorial Leadership Questionnaire para avaliar a liderança e as variáveis de resultado organizacional. Resultados: os estilos de liderança predominantes foram 0 transformacional (média 3,43) e transacional $(3,40)$, os quais apresentaram alta correlação com satisfação, eficácia e esforço extra. A liderança corretiva ou evitadora foi a menos percebida pela equipe $(2,10)$. Na liderança transformacional, a influência comportamental e a motivação inspiracional apresentaram melhores pontuações segundo a autopercepção dos líderes. Foram evidenciadas diferenças estatisticamente significativas com idade, estado civil e ter filhos com a liderança transformacional e transacional; a experiência profissional foi significativa com a liderança transacional. Conclusões: os profissionais de enfermagem denotam em seu desempenho 0 estímulo de práticas próprias da liderança transformacional, o que está relacionado com mudanças na cultura organizacional, leva a motivar e inspirar os seguidores para transcender a rotina, aumenta sua satisfação e comprometimento com o trabalho, sendo um fator importante nas instituições de saúde.

\section{PALAVRAS-CHAVE (Fonte: DeCS)}

Liderança; enfermagem; administração hospitalar; gestão em saúde; pessoal de saúde.

\footnotetext{
* Este artigo deriva da dissertação de mestrado intitulada "Estilos de liderança em enfermagem e fatores sociodemográficos associados. Percepção de líderes e classificadores de uma instituição de saúde de terceiro nível de atenção da cidade de Bucaramanga", apresentada ao Programa de Mestrado em Gestão de Serviços de Saúde da Universidad de Santander, Bucaramanga, Colômbia.
} 


\section{Introduction}

The need to attain high-quality levels in health, globalization in medical technologies, the users' preferences and the reforms of the health systems have led to the search for high-quality care and provision of services. These changes are innovating the organizational culture of health institutions, which requires new approaches and implies administrative challenges regarding the roles and putting skills into practice; mainly in essential aspects such as leadership by the Nursing staff, which allows for better performance in care management and in the provision of care in the operative scope, without leaving aside the organizations' technical and financial components, indispensable elements in the management of health services to face such changes. The adequate implementation of these changes will be determined by the context and by the leadership ability of their human talent (1-2).

Leadership is fundamental for the efficient development of the services, the provision of health care and, finally, for the health systems, thus becoming a basic component of health management and the most influencing factor in the organizational culture of such institutions, as asserted by the World Health Organization (WHO) (3).

In addition, several research studies report a positive association between leadership and the results in health institutions, the following among them: the quality of the health outcomes, the institution's financial performance and client satisfaction, as well as the staff's satisfaction and commitment (4). It is for this reason that, in the last few decades, fostering efficient leadership practices has been encouraged to improve the health outcomes; research in this field has also been promoted because Nursing is the cornerstone of any health system, has greater labor representation, and exerts a significant impact on patients' health. For Nursing, leadership is a basic competence that allows influencing, guiding, motivating and directing others to attain organizational effectiveness (5-6).

In the international scope, most of the studies on Nursing leadership focus on the styles (for example: transactional, transformational, autocratic, bureaucratic or democratic) and on how these influence the organizational culture, the work environment, the patients' outcomes, and the relationships between leaders and subordinates (7-8). Some studies conducted in hospitals show that Nursing professionals prefer the transformational leadership style, which promotes satisfaction at work and professional performance and reduces job changes, which improves retention of the Nursing staff in the organizations $(5,9-10)$. Other studies have reported positive associations between transactional and transformational leadership styles and organizational commitment and work satisfaction (9). In México, Hernández et al. (11) studied Nursing leadership in public hospitals from different states of the country. The most important findings show a trend towards managerial practices of a transactional nature, where a greater correlation is evidenced between leadership and the seniority and staff shift variables. In South America, the number of recent studies reported on leadership in hospital Nursing staff is scarce. In Chile, Cárcamo-Fuentes and Rivas-Riveros (1) evidenced that assistance Nursing professionals develop the transformational and transactional styles to a lesser extent. On the other hand, González et al. (12) found that leadership is associated with work satisfaction in hospitalization services for adults in the areas of Medicine and Surgery. In Brazil, and using qualitative methods, De Souza (13) addressed the perception of Nursing professionals in managerial positions in different health institutions and found that these professionals understand leadership as a process that exerts an influence on people and on behaviors, in addition to being a skill that can be learned. Characteristics such as commitment, flexibility, effective communication, responsibility, good interpersonal relationships, creativity, organization and knowing how to listen are necessary to work in a leadership position. Balsanelli et al. (14) also studied the association between the leadership styles and the nurse's personal and professional profile with a member of their intensive care service team in Brazil. They did not find statistically significant associations, but they reported predominance of the persuading style, followed by determining and by sharing in the leaders towards their subordinates.

Three recent studies were found in Colombia. Only one of them addressed leadership in Nursing professionals working at the hospital level. Valderrama (15) conducted a study on three successful cases of Nursing leadership, all of them related to managerial positions in health and educational institutions. Rozo and Abaunza (2) studied the correlation between sociodemographic and work variables and the transformational and transactional leadership styles in nurse-professors; however, they did not find any relationship between the leadership styles and the variables studied.

On the other hand, Torres (16) investigated the situational leadership styles present in the Nursing professionals from the 
hospitalization and intensive care services. In this study, there was a predominance of guiding in the hospitalization nurses' style, and of participating in that of the intensive care nurses. In addition, it related the directing leadership style and the experience time in the clinical area, although without finding any association between the leadership style and the time working in the institution. When considering the importance of Nursing leadership for personal and institutional performance, and given the limited number of research studies in Colombia, it is necessary to deepen this topic in the hospital scope from the new leadership theories, as long as they are consistent with the changing and complex context faced by the care system in this realm. Therefore, this study aims at assessing the leadership styles of the assistance Nursing professionals according to the following research question: Which are the Nursing leadership styles and the associated sociodemographic and professional factors, from the perspective of leaders and evaluators from a tertiary-level health care institution in the city of Bucaramanga, Colombia?

\section{Methodology}

An analytical and cross-sectional study. The sample comprised 75 Nursing professionals (coordinating nurses or nurses working in the services) and 170 Nursing assistants working in the assistance area of a tertiary-level public health care institution in Bucaramanga, Colombia, during the first four-month period of 2020. Non-probabilistic and for convenience sampling was carried out, where a minimum sample size of 75 Nursing professionals and 75 Nursing assistants was calculated, considering a $95 \%$ confidence interval, $80 \%$ power, and an expected means difference of 0.33 with a variance of 0.25 in the leadership score. The following inclusion criteria were considered: assistance Nursing professionals and assistants with employment contracts and a minimum work experience of four months in the institution, at least 6 months of personal experience of their own, and accepting to participate by signing the informed consent. No exclusion criteria were defined.

The version validated in Chile by Vega and Zavala (17) of the Multifactor Leadership Questionnaire, short version (MLQ-5X) was used for this research, with a version for the leaders and another for the evaluators or subordinates. This instrument is based on the Full Range Leadership Model comprised of 82 items, of which 65 are hierarchically organized by first- and second-order variables to assess leadership and 17 assess organizational results.
It distinguishes three leadership styles or first-order variables: transactional, transformational, and corrective/avoidance. The second-order variables are sub-variables that allow valuing and identifying the three styles. The variables are assessed according to the score of the attitudes and behaviors perceived by the leaders themselves and their evaluators, through a Likert-type scale with the following scores: $0=$ Never, $1=$ Rarely, $2=$ Sometimes, 3 = Often; and 4 = Frequently, if not always. Each variable has a score, which means that the higher their score, the greater the presence of the behaviors and attitudes which characterize it. All the scores obtained are added up as a final step (17). On the other hand, the organizational consequences and results are effectiveness, additional effort and satisfaction, aspects which are generally associated with transformational leadership (16). Each of them is defined below:

- Effectiveness: leader's actions targeted at harmonic teamwork and at good use of the resources, which leads to the subordinates meeting the objectives efficiently and effectively.

- Additional effort: greater participation and motivation of the subordinates towards attaining the objectives thanks to the leader's actions which stimulate participation through motivational rewards.

- Satisfaction: the extent to which the subordinates feel at ease with their work, environment and the entire organization. Feeling at ease with their work environment and the positive relationship between their effort, results and work demands exert a positive influence on the results (16).

The following sociodemographic and work variables were also assessed: age ( $<30$ years old, 31-40 years old, $>40$ years old), gender (male and female), marital status (with and without a partner), number of children (with and without children), university schooling level (technician, undergraduate and postgraduate), type of contract (fixed-term and undefined), the current area of residence (rural or urban), workplace or hospital service (Gynecology and delivery room, general surgery and surgical specialties, operating rooms, adult and pediatric urgencies, Internal Medicine, burns, adult and pediatric intensive care units, and external consultation), simultaneous work as a nurse in another institution (yes and no), and work experience (0-3 months, 1-3 years, 3-5 years, 5-15 years, and more than 15 years).

After obtaining due to written informed consent, the information was collected through a link sent via WhatsApp. The par- 
ticipants filled out the questionnaires via Google Forms, and the database was collected in Excel to then contrast possible inconsistencies and refine the data. Finally, the database was exported to the STATA 14 statistical program for analysis. A univariate analysis was performed to describe the qualitative variables through proportions, in addition to assessing the distribution of the quantitative variables of the leadership style levels using the ShapiroWilk normality test. As normal distribution was not found, medians and the 25 and 75 percentile values were reported. In addition, non-parametric tests were performed in the bivariate analysis, as follows: Wilcoxon's to compare the scores in the dichotomous variables, Kruskal-Wallis' in polytomous variables, and Pearson's correlation coefficient for quantitative variables, based on the following interpretation: $r=1$, perfect correlation; above 0.80 , very strong; between 0.60 and 0.80 , strong; between 0.40 and 0.60 , moderate; between 0.20 and 0.40 , low; between 0 and 0.20 , very low; and $r=0$ null. A $p$-value below 0.05 was considered as statistical significance (18).

Regarding the ethical aspects, the guidelines issued by the Council of International Medical Sciences Organizations (Consejo de Organizaciones Internacionales de las Ciencias Médicas, CIOMS) and the rules set forth by the Colombian Ministry of Health in Resolution 8,430 of October $4^{\text {th }}$, 199rs are graduated Nu3, were taken into consideration. The research was approved by the Ethics Committee of Santander's University Hospital (Minute 9000SSAC-000020-2020). In addition, personal data were safeguarded according to Colombian Decree No. 1,377 of 2013.

\section{Results}

Regarding the identification of the leaders' and evaluators' sociodemographic characteristics, they were mostly women, with $80 \%$ (leaders) and $91 \%$ (evaluators). The predominant marital status was no partner, both among the leaders and among the evaluators and, regarding having children, it was identified in most of the evaluators. Both the leaders and the evaluators live in the metropolitan area of the city, considered as Bucaramanga, Girón, Floridablanca and Piedecuesta. Regarding schooling, $62.67 \%$ of the leaders have graduated Nursing professionals, $33 \%$ have some specialization, and $4 \%$ some master's post-graduate degree. All the evaluators are Nursing technicians. $92 \%$ of the Nursing staff working in the institution are nurses from gen- eral hospitalization services and $8 \%$ act as coordinators. In the case of the evaluators, they are all Nursing technicians. Regarding their work experience, both the leaders and the evaluators mostly reported from 5 to 15 years and the nurse-leaders stated having no parallel job outside the institution; however, $7.65 \%$ of the evaluators do have a second job. The institution's staff has a fixed-term contract.

In relation to the service in which they were working at the time of the survey, $46.66 \%$ of the nurse-leaders and $55.87 \%$ of the evaluators do so in hospitalization services (Internal Medicine, Postoperative, Pediatrics and Gynecology/Delivery Room), $13.33 \%$ of the leaders and $7.65 \%$ of the evaluators work in intensive care units, $10.67 \%$ of the leaders and $7.65 \%$ of the evaluators work in adult and pediatric urgencies, $5.33 \%$ of the leaders and $7.65 \%$ of the evaluators work in surgery rooms (operating rooms) and $5.3 \%$ of the leaders and $5.88 \%$ of the evaluators work in the burns unit. The rest of the nurse-leaders, $18.67 \%$, and $15.89 \%$ of the evaluators work in services related to intrahospital support special programs.

Table 1 shows the scores obtained in the leadership scores, where the perception of transformational leadership stands out, followed by the transactional and corrective/avoidance styles. On the other hand, both in the transformational and transactional styles, the leaders' perception was higher than the evaluators'. Regarding corrective/avoidance leadership $(1,8)$, a lower median was evidenced in the answers obtained in both groups (leaders and evaluators). In the transformational leadership style, the third-order variables, behavioral influence and inspirational motivation, presented better scores in the leaders' results. In the case of the evaluators, the results were similar in these two variables, and a third high score was obtained for idealized influence.

In transactional leadership, the individualized consideration and contingent reward variables obtained the same score values from the leaders' perspective; however, in the evaluators' scores, it was evidenced that contingent reward scored higher although presenting lower median values when compared to those reported in the leaders' results. In the case of corrective/ avoidance leadership, in the leaders' results it was evidenced that active management by exception obtained a higher score when compared to passive avoidance leadership comprised by passive management by exception and laissez-faire, with lower scores. 
Table 1. Leadership styles in Nurses according to a hierarchy of variables

\begin{tabular}{|c|c|c|c|c|}
\hline $\begin{array}{l}\text { First-order } \\
\text { variables }\end{array}$ & Second-order variables & $\begin{array}{l}\text { Third-order } \\
\text { variables }\end{array}$ & $\begin{array}{l}\text { Leader } n=75 \\
\text { Median (IQR) }\end{array}$ & $\begin{array}{c}\text { Evaluator } n=170 \\
\text { Median (IQR) }\end{array}$ \\
\hline \multirow{5}{*}{$\begin{array}{c}\text { Transformational } \\
\text { Leadership } \\
\text { (TFL) }\end{array}$} & \multirow{3}{*}{ Charisma - C/I } & Idealized Influence - II & $3.57(3.00,4.00)$ & $3.00(2.29,3.57)$ \\
\hline & & Behavioral Influence - BI & $3.63(3.13,3.88)$ & $3.00(2.38,3.50)$ \\
\hline & & $\begin{array}{c}\text { Inspirational Motiva- } \\
\text { tion - IM }\end{array}$ & $3.63(3.25,4.00)$ & $3.00(2.38,3.63)$ \\
\hline & \multicolumn{2}{|l|}{ Total } & $3.56(3.24,3.86)$ & $3.01(2.33,3.54)$ \\
\hline & \multicolumn{2}{|l|}{ Intellectual Stimulation - IS } & $3.25(3.00,3.63)$ & $2.50(2.00,3.13)$ \\
\hline \multicolumn{3}{|l|}{ Total (TFL) } & $3.43(3.08,3.74)$ & $2.80(2.15,3.35)$ \\
\hline \multirow{2}{*}{$\begin{array}{l}\text { Transactional } \\
\text { Leadership }\end{array}$} & \multicolumn{2}{|c|}{ Individualized Consideration - IC } & $3.50(3.00,3.75)$ & $2.63(2.00,3.25)$ \\
\hline & \multicolumn{2}{|l|}{ Contingent Reward - CR } & $3.50(3.17,3.83)$ & $2.83(2.00,3.50)$ \\
\hline \multicolumn{3}{|l|}{ Total (TRL) } & $3.40(3.13,3.75)$ & $2.72(2.00,3.31)$ \\
\hline \multirow{4}{*}{$\begin{array}{c}\text { Corrective/ } \\
\text { Avoidance } \\
\text { Leadership } \\
\text { (C/AL) }\end{array}$} & \multicolumn{2}{|c|}{ Active Management by Exception - MBE active } & $3.00(2.67,3.50)$ & $2.83(2.17,3.50)$ \\
\hline & \multirow{2}{*}{$\begin{array}{l}\text { Passive Avoidance } \\
\text { Leadership - PAL }\end{array}$} & $\begin{array}{l}\text { Passive Management by } \\
\text { Exception - MBE passive }\end{array}$ & $1.00(0.50,1.50)$ & $1.50(0.83,2.00)$ \\
\hline & & Laissez-faire - LF & $1.25(0.88,1.75)$ & $1.38(0.75,1.88)$ \\
\hline & \multicolumn{2}{|l|}{ Total } & $1.17(0.75,1.65)$ & $1.47(0.90,1.85)$ \\
\hline \multicolumn{3}{|l|}{ Total (C/AL) } & $2.10(1.79,2.48)$ & $2.10(1.79,2.41)$ \\
\hline
\end{tabular}

Source: Own elaboration.

Regarding the variables considered as reactive and which assess the organizational consequences and results, it was found that satisfaction and additional effort obtained higher scores than effectiveness. Likewise, from the evaluators' perspective, the results were low in the three variables of organizational results (Table 2).
When exploring the correlation of these result variables with the leadership styles (Table 3), it was found that the transformational and transactional styles presented a strong correlation with all the result variables when compared to corrective/avoidance leadership. Likewise, transformational leadership presented a greater correlation with satisfaction, so 
did transactional leadership with efficacy. Finally, statistically significant differences between the age, marital status and having children variables were found for the transformational and transactional leadership styles; whereas the transactional leadership style was only statistically significant with work experience (Table 4). The other sociodemographic variables did not present statistically significant differences with the leadership styles under study.

Table 2. Variables with organizational results

\begin{tabular}{|c|c|c|}
\hline Variables with organizational results & Leader $\mathbf{n = 7 5}$ Median (IQR) & Evaluator $\mathbf{n = 1 7 0 ~ M e d i a n ~ ( I Q R ) ~}$ \\
\hline Satisfaction & $3.60(3.20,4.00)$ & $3.00(2.40,3.60)$ \\
\hline Effectiveness & $3.33(2.83,3.83)$ & $2.83(2.17,3.50)$ \\
\hline Additional effort & $3.50(3.00,3.67)$ & $3.00(2.17,3.67)$ \\
\hline
\end{tabular}

Source: Own elaboration.

Table 3. Correlation between organizational variables and leadership styles

\begin{tabular}{|c|c|c|c|}
\hline \multirow{2}{*}{ Variable } & Satisfaction & Efficacy & Additional Effort \\
\cline { 2 - 4 } & Correlation coefficient & Correlation coefficient & Correlation coefficient \\
\hline Transformational Leadership & $0.77 *$ & $0.77 *$ & $0.71 *$ \\
\hline Transactional Leadership & $0.70 *$ & $0.79 *$ & $0.71 *$ \\
\hline Corrective/Avoidance Leadership & 0.19 & $0.30 * \star$ & 0.18 \\
\hline
\end{tabular}

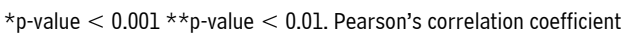
Source: Own elaboration.

Table 4. Perception of the leadership styles by the Nursing professionals according to age, gender, marital status, children, job position, schooling level and experience.

\begin{tabular}{|c|c|c|c|c|c|c|}
\hline $\begin{array}{c}\text { Socio-demographic } \\
\text { Variables }\end{array}$ & $\begin{array}{l}\text { Transformational } \\
\text { Leadership }\end{array}$ & $\mathrm{p}$-value & $\begin{array}{l}\text { Transactional } \\
\text { Leadership }\end{array}$ & p-value & $\begin{array}{c}\text { Corrective/ } \\
\text { Avoidance Leadership }\end{array}$ & p-value \\
\hline \multicolumn{7}{|c|}{ Age } \\
\hline$<31$ years old & $3.35(3.07,3.61)$ & \multirow{3}{*}{$0.03 *$} & $3.32(3.02,3.59)$ & \multirow{3}{*}{$<0.01^{*}$} & $2.09(1.80,2.43)$ & \multirow{3}{*}{0.15} \\
\hline $31-40$ years old & $3.22(3.03,3.75)$ & & $3.42(3.06,3.67)$ & & $1.99(1.72,2.27)$ & \\
\hline$>41$ years old & $3.62(3.39,3.80)$ & & $3.73(3.38,3.85)$ & & $2.33(2.04,2.56)$ & \\
\hline \multicolumn{7}{|c|}{ Gender } \\
\hline Male & $3.09(2.25,3.39)$ & \multirow{2}{*}{$0.49 *$} & $3.00(2.33,3.42)$ & \multirow{2}{*}{$0.35 \star$} & $2.01(1.86,2.36)$ & \multirow{2}{*}{$0.65 *$} \\
\hline Female & $2.77(2.15,3.35)$ & & $2.67(2.00,3.25)$ & & $2.10(1.78,2.43)$ & \\
\hline
\end{tabular}




\begin{tabular}{|c|c|c|c|c|c|c|}
\hline $\begin{array}{c}\text { Socio-demographic } \\
\text { Variables }\end{array}$ & $\begin{array}{l}\text { Transformational } \\
\text { Leadership }\end{array}$ & $\mathrm{p}$-value & $\begin{array}{l}\text { Transactional } \\
\text { Leadership }\end{array}$ & $\mathrm{p}$-value & $\begin{array}{c}\text { Corrective/ } \\
\text { Avoidance Leadership }\end{array}$ & p-value \\
\hline \multicolumn{7}{|c|}{ Children } \\
\hline No children & $3.23(3.02,3.61)$ & \multirow{2}{*}{$0.03 *$} & $3.33(2.97,3.65)$ & \multirow{2}{*}{0.01} & $2.06(1.78,2.37)$ & \multirow{2}{*}{$0.34 *$} \\
\hline With children & $3.58(3.26,3.77)$ & & $3.67(3.29,3.79)$ & & $2.13(1.89,2.50)$ & \\
\hline \multicolumn{7}{|c|}{ Marital status } \\
\hline With a partner & $3.22(3.01,3.58)$ & \multirow[b]{2}{*}{$<0.01$} & $3.33(3.02,3.71)$ & \multirow[b]{2}{*}{0.02} & $2.06(1.77,2.33)$ & \multirow[b]{2}{*}{0.21} \\
\hline No partner & $3.62(3.37,3.85)$ & & $3.64(3.29,3.85)$ & & $2.17(1.92,2.50)$ & \\
\hline \multicolumn{7}{|c|}{ Work experience } \\
\hline$<3$ months & $3.14(3.04,3.54)$ & \multirow{5}{*}{$0.20 * \star$} & $3.30(3.00,3.33)$ & \multirow{5}{*}{$0.02 \star \star$} & $2.12(1.86,2.31)$ & \multirow{5}{*}{0.94} \\
\hline $1-3$ years & $3.46(3.13,3.62)$ & & $3.42(3.02,3.75)$ & & $2.04(1.82,2.23)$ & \\
\hline 3-5 years & $3.43(3.00,3.47)$ & & $3.13(3.06,3.35)$ & & $2.07(2.00,2.31)$ & \\
\hline $5-15$ years & $3.36(3.08,3.79)$ & & $3.63(3.19,3.77)$ & & $2.06(1.72,2.66)$ & \\
\hline$>15$ years & $3.60(3.38,3.79)$ & & $3.71(3.38,3.85)$ & & $2.14(1.97,2.48)$ & \\
\hline \multicolumn{7}{|c|}{ Job position } \\
\hline Nurse & $3.43(3.08,3.62)$ & \multirow{2}{*}{$0.52^{*}$} & $3.38(3.23,3.73)$ & \multirow{2}{*}{$0.64 *$} & $2.08(1.77,2.33)$ & $0.17^{\star}$ \\
\hline Coordinator & $3.45(3.03,3.81)$ & & $3.59(3.04,3.85)$ & & $2.13(1.90,2.64)$ & \\
\hline
\end{tabular}

*Wilcoxon's test **Kruskal-Wallis test Source: Own elaboration.

\section{Discussion}

This research was conducted according to the Full Range Leadership Model framework, which explores three leadership styles considered as first-order variables, namely: transactional, transformational and corrective/avoidance. It was found that there is no predominant leadership style, since slightly higher scores were obtained in transformational leadership versus transactional leadership, and significantly higher when compared to the corrective/avoidance style in the Nursing staff that selfevaluated themselves and that was evaluated by the subordinates or evaluators (Nursing technicians). These results were consistent with what Bass and Avolio pointed out regarding the fact that an efficient leader will present all the full-range styles to some extent, along with a minimum frequency of laissez-faire and a gradual increase of the transactional variables to achieve a high frequency of transformational variables (2).
Authors like Cárcamo-Fuentes and Rivas-Riveros reported results without significant differences in their research. The first is the transformational leadership style, followed by transactional leadership in Nursing professionals (1), findings which are similar to those of this research. In opposition to the results of other studies, where transformational leadership was predominant over transactional leadership in terms of management, the development of these two styles can vary and be related to the type, operation, context, environment and culture of the organization, in addition to how the achievement of objectives is planned (19).

On the other hand, the findings by Pucheu (20) and those of this research were in consonance, for obtaining better scores in this corrective/avoidance leadership style. This symbolizes that the perspectives on leadership assessed in the Nursing staff in their field and performance as leaders are related to behaviors characterized by the low resolution of the teams' problems without the 
adequate guidance and support of the activities to be performed. Likewise, Cárcamo and Cols (1) found low values in the scores of the laissez-faire dimension, as was also the case in the study by Hernández and Duana (11). The results of this research evidenced that passive management by exception and laissez-faire presented the lowest values, in opposition to active management by exception, which obtained a higher score.

Based on the findings of the variables that comprise the transformational leadership style, charisma, behavioral influence, inspirational motivation and idealized influence presented high scores in various studies $(5,21-22-23)$, as was the case in our research. The preceding aspects must be strategically acknowledged from productivity and management, as transformational style leaders are often charismatic, which allows them to act as role models and to influence their subordinates based on trust towards the leader in the achievement of objectives and on admiration towards them, applied to the health assistance processes and leading teamwork.

Therefore, with these data we can deduce that the Nursing leaders relate and identify themselves with transformational style attitudes; although there was no significant difference between these two styles, transformational leadership was slightly higher when compared to the transactional style. In this sense, the literature reports that the Nursing practice and the transformational leadership style are related, and that such relationship can exert an impact on the quality of the care provided to the patient by creating work environments that empower the Nursing professional in the management of work teams to offer optimum care. In addition, this style highlights the communication strengths as an aspect that is reflected on their subordinates, which inspires them and turns them into active participants of the organizations' strategic planning (mission and vision) and, in turn, is related to the staff's work satisfaction $(10,22,24-25)$.

In the case of the intellectual stimulation and idealized influence dimensions, Hernández and Duana (11) reported low scores, a finding that is correlated with the results of our research. This would be considered as an aspect to be improved and worked on from the organizational and management component, if the aim is to implement the development of leadership in the institution, since certain characteristics are strengthened in the leaders that will help them to offer the work teams the guidance and motivation needed towards high performance in their duties.
A number of studies in which leadership was assessed reported high scores in one of these two dimensions: individualized consideration and reward (10-11, 21-22), results which were similar in our research. The aforementioned can be considered from the managerial scope as characteristics of the leaders and which are related to their work context. The literature has shown that this type of leadership is related to how companies operate: the starting point is achievement planning by means of numerical goals or objectives, in addition to being recognized as a fundamental cornerstone to which quality care is provided to people is attributed (26). Therefore, the reward becomes the core of transformational leadership. Although none of the leadership styles was predominant in our research, the transactional style also characterized our sample. It is therefore inferred that the Nursing work and the management modality can be related to health recovery, maintenance and rehabilitation.

The relationship between the transactional leadership factors, especially contingent reward, asserts that these leadership styles are active and positive forms of leadership dimensions (25). Consistency in transactional leadership behaviors and the trust developed because of effort are the foundation for transformational leadership.

Regarding the correlation between the leadership styles and the organizational variables, it is noted that the transformational and transactional leadership styles were significantly correlated with all the result variables; however, in the case of transformational leadership, it was strongly correlated with satisfaction, whereas transactional leadership showed a correlation with efficacy (12).

The literature on leadership determined that satisfaction is a high-impact factor in relation to leadership, especially to transformational leadership $(8-9,12-13,15,27)$. In this sense, and from the managerial perspective, it must be taken into account why such association yields good results on the health professionals in the organizations, particularly in the Nursing staff, which corresponds to the majority of the permanent personnel in the institutions and are those who assume care and team management in the assistance and strategic processes.

Given the above, it is indispensable to have leadership and managerial competencies that allow guiding teamwork, decisionmaking, and the planning of activities to attain the mission objectives. In addition, becoming a role model through the motivation 
to be excellent professionals and care providers, committed to the institutions in full compliance of the mission activities, which were agreed upon and that, in turn, this can be verified in the quality and user's satisfaction indicators.

Regarding the sociodemographic factors that were statistically associated with the perception of leadership by the leaders, it was found that gender and type of job position did not present statistically significant differences with any type of leadership. Non-association of gender with leadership was also similar to the finding of a study conducted with Saudi Arabian female nurses (30).

According to the findings in which leadership in the Nursing staff was assessed, most of this population is made up by women, as shown by the results of our research, where it was evidenced that $80 \%$ of the group of leaders and $91 \%$ of the evaluators were women, as was the case with the data reported by several authors $(1,9,10-11,19,27,29)$. In this sense, in the health area it can be extremely useful since in hospital centers human talent is generally made up by women, who can come to lead according to the characteristics of effective leadership depending on the context of their organization or on the type of leadership that is intended to develop. However, transformational leadership leads to the better attainment of organizational goals, team performance, work satisfaction, staff retention, and patient safety.

Regarding the time of performance, Hernández and Duana (11), just as in this research, found that the Nursing staff mostly provides its services in two assistance areas: hospitalization and intensive care units. The health institutions' internal organization is made up of these types of units in service provision, the reason why it is considered important to recognize the job position profiles and their initiative to establish a leadership style policy that is acknowledged both for the hospitalization area and for the critical care area. The aforementioned considering that both hospital contexts are different in relation to care and team management, and to goals attainment mediated by the care demand from Nursing and the entire health team.

The data obtained in this study regarding work experience showed that $41.33 \%$ stated having from 5 to 5 years of experience in the assistance scope, differently from the results by Naseer et al. (10), where only $16.4 \%$ of the Nursing staff had more than 5 years of experience. This fact was related in a statistically significant way only to the transactional leadership style in our research, as was the case with the studies by Cárcamo-Fuentes and Rivas-Riveros (1) and by Hernández and Duana (11). Work experience must be understood as task learning and as the feedback which has provided over time; therefore, the leaders in the organizations must not only consider the attitudinal and behavioral aspect but also that of knowledge, which can have a bearing on the provision of pertinent, timely and quality services.

On the other hand, regarding age, Moon et al. (19) and Pucheu (20) showed similar results to those of this research when positively relating them with the development and influence of the transformational and transactional leadership styles (31). This aspect is relevant when it comes to striking a balance in the institutions regarding the age of the human talent which allows favoring behaviors to conduct work teams, hierarchy, achievements and goals proposed in the development of the activities.

As was the case with the results of the research by Clavelle et al. (32), not having a partner and having children were predominant in this study. These variables showed a statistically significant relationship with the transformational and transactional styles; however, no other study was found reporting this type of association. This result can be related to the fact that people who do not have a partner create a stronger bond with the workplace, as it is there that they spend most of their time and can relate their job with a family setting, which could be related to staff retention, institutional commitment and work satisfaction (33-34).

On the other hand, no relationship between the leadership styles and characteristics such as type of job position was found in this study, that is, whether the person is a nurse or a coordinator. A possible reason for this is that the Nursing staff role is considered as one of service head or leader. In addition, to the identification of the Nursing staff in the institutions as process leaders in the organization's scheme, we must add an integral command structure where the nurse is part of the comprehensive care processes, support and strategic processes.

Based on the findings, it is recommended that, for future research, intervention studies aimed at strengthening transformational and transactional leadership are developed, based on the $M L Q-5 X$ instrument for baseline and follow-up measurements. In addition, prospective studies for the follow-up of the leadership style and level of the Nursing professionals can be conducted, as well as assessing the association of leadership with objectives results or hospital care and patient safety indicators. 


\section{Conclusions}

Nursing leadership is a fundamental characteristic for work performance, which is directly determined by specific dimensions to be explored in each of the Nursing professionals, either by themselves or by their subordinates, which result in the practice of transformational, transactional, or corrective/avoidance leadership. In this study, the transformational and transactional leadership styles were predominant.

The perception of transformational leadership in this population group was related to dimensions such as charisma, comprised by the behavioral influence and inspirational motivation sub-variables. Regarding transactional leadership, the contingent reward was predominant among the variables for the evaluators.

The corrective/avoidance leadership style was the one with which the leaders and evaluators identified the least. This proves that the institutions' Nursing staff stands out for practicing effective and active leadership in the face of the mission and strategic processes in the integral command structure.

The fact that no predominant leadership style has been found in this study can be due to the health assistance context where the outsourced Nursing staff targets its leadership actions towards attaining concrete objectives in a certain time frame, which can lead to the maintenance of behaviors directed to the transactional leadership style during the provision of health services.

Contrary to what was expected, the transformational leadership style was the one that obtained the highest score. This finding is promising for the health institution under study since, although the Nursing staff and in general the entire personnel is outsourced, the team of leaders is encouraging practices that are inherent to transformational leadership, which is related to changes in the organizational culture. Transformational leadership motivates and inspires the subordinates to transcend the routines, increases their satisfaction and commitment levels, and allows leaders to gradually train new leaders.

The transformational and transactional leadership styles presented a strong correlation with organizational results such as satisfaction, efficacy and additional effort. In addition, of the sociodemographic variables, age, marital status and having children presented significant differences with the transformational and transactional leadership styles; as was the case with work experience in the transactional leadership style.

\section{Strengths and limitations}

A strength of this study is the rigor observed in the research process. The pilot test allowed discerning difficulties which enabled devising sampling and information collection strategies according to the work context and time availability of the Nursing staff from the health institution. The most important limitation of this paper is that, because convenience sampling was used and that the sample was obtained from a single health institution, the results cannot be generalized to the population of public highcomplexity assistance institutions.

Conflict of interest: None declared. 


\section{References}

1. Cárcamo-Fuentes Claudio, Rivas-Riveros Edith. Estilo de liderazgo en profesionales de enfermería según su función en los sectores público o privado en Temuco. Aquichan [Internet] 2015; 17(1):73-80. DOI: https://doi.org/10.5294/ aqui.2017.17.1.7

2. Rozo S, Abaunza M. Liderazgo transaccional y transformacional. Avances en Enfermería. 2010; 28(2):62-72. Disponible en: http://www.scielo.org.co/pdf/aven/v28n2/v28n2a06.pdf

3. Al-Yami M, Galdas P, Watson R. Leadership style and organisational commitment among nursing staff in Saudi Arabia. J Nurs Manag. 2018; 26(5):531-9. DOI: https://doi.org/10.1111/jonm.12578

4. Sfantou D, Laliotis A, Patelarou A, Sifaki-Pistolla D, Matalliotakis, Michail Patelarou E. Importance of Leadership Style towards Quality of Care Measures in Healthcare Settings: A Systematic Review. Healthcare. 2017; 5(73):1-17. DOI: https://doi.org/10.3390/healthcare50400735

5. Naseem S, Afzal M, Sehar S, Gilani SA. Relationship between Leadership Styles of Nurse Managers and Staff Nurses Job Satisfaction in Public Hospital of Punjab, Pakistan Relationship between Leadership Styles of Nurse Managers and Staff Nurses Job Satisfaction in Public Hospital of Punjab, Pa. Int J Soc Sc Manag. 2018; 5(3August):201-8. DOI: https://doi. org/10.3126/ijssm.v5i3.20611

6. De Arco-Canoles O, Suarez-Calle Z. Rol de los profesionales de enfermería en el sistema de salud colombiano. Univ Salud. 2018; 20(2):171-82. DOI: http://dx.doi.org/10.22267/rus.182002.121

7. Fusari Mônica Emanuele Köpsel, Meirelles Betina Hörner Schlindwein, Lanzoni Gabriela Marcellino de Melo, Costa Veridiana Tavares. Best leadership practices of nurses in hospital risk management: case study. Rev. Gaúcha Enferm. 2021; 42(esp):e20200194. DOI: https://doi.org/10.1590/1983-1447.2021.20200194

8. Fallatah F, Laschinger HK. The influence of authentic leadership and supportive professional practice environments on new graduate nurses' job satisfaction. Journal of Research in Nursing. 2016; 21(2):125-136. DOI: https://doi. org/10.1177/1744987115624135

9. Morsiani G, Bagnasco A, Sasso L. How staff nurses perceive the impact of nurse managers' leadership style in terms of job satisfaction: a mixed method study. J Nurs Manag. 2017; 25(2):119-128. DOI: https://doi.org/10.1177/1744987115624135

10. Naseer A, Perveen K, Afzal M, Waqas A, Syed P, Gillani A. The Impact of Leadership Styles on Staff Nurses' Turnover Intentions. Saudi J Med Pharm Sci. 2017; 4929(10B):1133-8. DOI: https://doi.org/10.21276/sjmps.2017.3.10.20

11. Hernández T, Duana D. Estudio diagnóstico de liderazgo transformacional en personal de enfermería que labora en hospitales públicos mexicanos. Rev Cimexus. 2018; 13(2):89-109. Disponible en: https://www.cimexus.umich.mx/index.php/cim1/article/view/292/231

12. Gonzalez L, Guevara E, Morales G, Segura P, Luengo C. Relación de la satisfacción laboral con estilos de liderazgo en enfermeros de hospitales públicos, Santiago, Chile. Cienc Y Enferm. 2013; XIX(1):11-21. DOI: http://dx.doi.org/10.4067/ S0717-95532013000100002

13. Souza e Souza Luis Paulo, Ferreira Cordeiro Ana Lúiza, Nunes de Aguiar Rodrigo, Veloso Dias Orlene, Vieira Ma Aparecida, Ramos Laís Helena. El liderazgo en la visión de Enfermeros Líderes. Enferm. glob. [Internet]. 2013; 12(30): 268-280. DOI: https://doi.org/10.6018/eglobal.12.2.154801

14. Balsanelli AP, Cristina I, Olm K, Con A, Perfil EL, Con PY, et al. Estilos de liderazgo de enfermeros en una unidad de terapia intensiva: asociación con el perfil personal, profesional y con la carga de trabajo. 2009; 17(1). DOI: http://dx.doi. org/10.1590/S0104-11692009000100005

15. Valderrama M. Experiencias exitosas de liderazgo en enfermeria. Rev Cuid. 2014; 5(2):765-73. DOI: http://dx.doi. org/10.15649/cuidarte.v5i2.89

16. Torres-Contreras CC. Liderazgo situacional en enfermeras de una institución de salud de Bucaramanga (Colombia). Enfermería Clínica [Internet]. 2013; 23(4):140-7. DOI: http://dx.doi.org/10.1016/j.enfcli.2013.04.004

17. Vega C, Zavala G. Adaptación del cuestionario multifactorial de liderazgo (MLQ Forma $5 X$ corta) de B. Bass y B. Avolio (Tesis). 2004; 1-295. Disponible en: http://www.tesis.uchile.cl/tesis/uchile/2004/vega_c/sources/vega_c.pdf 
18. Leyva O, Flores M. Análisis de correlaciones bivariadas y parciales con SPSS. En: Sáenz K,Tamez G. Métodos y técnicas cualitativas y cuantitativas aplicables a la investigación en ciencias sociales. México D.F.: Tirant Humanidades; 2014. Disponible en: http://eprints.uanl.mx/8625/1/7.\%20Metodolog\%C3\%ADa\%20cap\%2019\%20solo\%20cap\%C3\%ADtulo.pdf

19. Moon SE, Van Dam PJ, Kitsos A. Measuring Transformational Leadership in Establishing Nursing Care Excellence. Healthcare (Basel). 2019; 7(4):132. DOI: http://dx.doi.org/10.3390/healthcare7040132

20. Pucheu A. Liderazgo de enfermeras supervisoras: ¿cómo influyen sobre las enfermeras clínicas? Horiz Enferm -Chi-. 2009; 13-26. DOI: https://doi.org/10.7764/Horiz_Enferm.20.1.13

21. Rivera Morales MI. Liderazgo que ejercen jefas y supervisoras según auto percepción y sus colaboradores. Rev Cienc y Arte Enfermería. 2019; 4(1):18-23. DOI: https://doi.org/10.24314/rcae.2019.v4n1.04

22. Boamah SA, Laschinger HKS, Wong C, Clarke S. Effect of transformational leadership on job satisfaction and patient safety outcomes. 2017; 1-10. DOI: https://doi.org/10.1016/j.outlook.2017.10.004

23. Jodar G, Gené J, Delgado P, Campo MA, Del Val Garciá J. Self-perception of leadership styles and behaviour in primary health care Organization, structure and delivery of healthcare. BMC Health Serv Res. 2016; 16(1):1-9. DOI: https://doi. org/10.1186/s12913-016-1819-2

24. De Moura AA, Bernardes A, Balsanelli AP, Zanetti ACB, Gabriel CS. Leadership and nursing work satisfaction: An integrative review. ACTA Paul Enferm. 2017; 30(4):442-50. DOI: http://dx.doi.org/10.1590/1982-0194201700055

25. Amestoy Simone Coelho, Trindade Letícia de Lima, Silva Gilberto Tadeu Reis da, Santos Bianca Pozza dos, Reis Virginia Ramos dos Santos Souza, Ferreira Vaneska Brito. Leadership in nursing: from teaching to practice in a hospital environment. Esc. Anna Nery [Internet]. 2017; 21(4): e20160276. DOI: https://doi.org/10.1590/2177-9465-ean-2016-0276

26. Lara Jaque, R. A, García Vallejos, G.A., Lorca Nachar, A. R, Montecinos Guiñez, D.A, Quijada Sánchez, D.C, Castillo Mancilla, D. Percepción de enfermeras/os de atención hospitalaria y primaria de salud, sobre el liderazgo de Enfermería. Cultura de los Cuidados (Edición digital), 2020; 24(58). DOI: http://dx.doi.org/10.14198/cuid.2020.58.07

27. Khanzada B, Naeem S, Butt H. Impact of Transformational Leadership on Job Satisfaction and Patient Safety Outcomes in Health Sector of Pakistan. J Heal Educ Res Dev. 2018; 06(02):1-10. DOI: http://dx.doi.org/10.4172/2380-5439.1000251

28. Boamah SA, Tremblay P. Examining the Factor Structure of the MLQ Transactional and Transformational Leadership Dimensions in Nursing Context. West J Nurs Res. 2019; 41(5):743-61. DOI: http://dx.doi.org/10.1177/0193945918778833

29. Balsanelli AP, Cunha ICKO. Nursing leadership in intensive care units and its relationship to the work environment. Rev Lat Am Enfermagem. 2015; 23(1):106-13. DOI: http://dx.doi.org/10.1590/0104-1169.0150.2531

30. Alghamdi MG, Topp R, AlYami MS. The effect of gender on transformational Leadership and job satisfaction among Saudi nurses. J Adv Nurs. 2018; 74(1):119-27. DOI: http://dx.doi.org/10.1111/jan.13385

31. Ferreira Vanêska Brito, Amestoy Simone Coelho, Silva Gilberto Tadeu Reis da, Felzemburgh Ridalva Dias Martins, Santana Neuranides, Trindade Letícia de Lima et al. Liderança transformacional na prática dos enfermeiros em um hospital universitário. Acta paul. enferm. [Internet]. 2018; 31(6):644-650. DOI: https://doi.org/10.1590/1982 0194201800088

32. Clavelle JT, Drenkard K, Tullai-Mcguinness S, Fitzpatrick JJ. Transformational leadership practices of chief nursing officers in magnet ${ }^{\circledR}$ organizations. J Nurs Adm. 2012; 42(4):195-201. DOI: https://doi.org/10.1097/NNA.0b013e31824ccd7b

33. Asiri SA, Rohrer WW, Al-Surimi K, Da'ar OO, Ahmed A. La asociación de estilos de liderazgo y empoderamiento con el compromiso organizacional de las enfermeras en un entorno de atención médica aguda: un estudio transversal. BMC Nurs. 2016; 15:38. DOI: https://doi.org/10.1186/s12912-016-0161-7

34. Kodama Y, Fukahori H, Sato K, Nishida T. Is nurse managers' Leadership style related to Japanese staff nurses' affective commitment to their hospital? J Nurs Manag. 2016; 24(7);887-92. DOI: https://10.1111/jonm.12392 